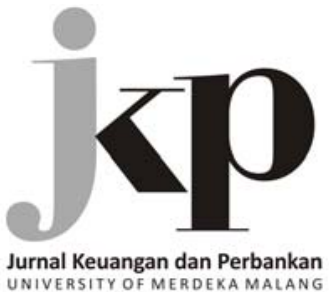

UNIVERSITY OF MERDEKA MALANG

Article history:

Received: 2017-11-21

Revised: 2018-03-01

Accepted: 2018-04-13

\section{Eko Suyono}

Department of Accounting, Faculty of Economics

and Business

Universitas Jenderal Soedirman

JI. HR. Bunyamin No.78

Purwokerto, 53122, Indonesia

$\triangle$ Corresponding Author:

\section{Eko Suyono:}

Tel. +62 281639643

E-mail: ekyo75@yahoo.com

\section{(c) (7) (2)}

This is an open access

article under the CC-BY-SA license

\section{Eko Suyono (Indonesia)}

\section{Family Involvement in Firm's Management and Productivity: An Empirical Evidence from Indonesia}

\begin{abstract}
This study aims to investigate the effect of family ownership on productivity, the difference on the productivity level between family managers and professional managers, and to evaluate whether family firm better to hire professional managers or family managers. Implementing purposive method on 535 companies listed on The Indonesian Stock Exchange in sampling technique, this study ended-up with 144 listed companies as a sample for five years (2011-2015), thus totally there are 720 company year observations. Then, this study uses OLS regression to test the hypotheses. The findings show that family ownership affects negatively on firm productivity which is measured by Standard Cobb-Douglas production function. Moreover, family managers are less productive than professional managers. Therefore, this study recommends the family firm hire professional managers to improve firm productivity. To the best of my knowledge, it is the first study which relates the family ownership and firm productivity in Indonesia. Thus it will be beneficial in knowledge development in this research field.
\end{abstract}

Keywords: Family Ownership; Family Firm; Family Manager; Professional Manager; Standard Cobb-Douglas Production Function

\section{JEL Classification: G32; M41}

Citation: Suyono, E. (2018). Family involvement in firm's management and productivity: An empirical evidence from Indonesia. Jurnal Keuangan dan Perbankan, 22(2), 256-275. https://doi.org/10.26905/jkdp.v22i2.1587.

\begin{abstract}
Abstrak
Penelitian ini bertujuan untuk mengetahui pengaruh kepemilikan keluarga terhadap produktivitas, perbedaan tingkat produktivitas antara manajer keluarga dan manajer profesional, dan untuk mengevaluasi apakah perusahaan keluarga lebih baik mempekerjakan manajer profesional atau manajer keluarga. Dengan menerapkan metode purposive dalam teknik sampling pada 535 perusahaan yang tercatat di Bursa Efek Indonesia, penelitian ini mendapatkan 144 perusahaan tercatat sebagai sampel selama lima tahun observasi (20112015), sehingga totalnya ada 720 observasi. Kemudian, penelitian ini mengounakan regresi OLS untuk menguji hipotesis. Temuan tersebut menunjukkan bahwa kepemilikan keluarga berpengaruh negatifterhadap produktivitas perusahaan yang diukur dengan fungsi produksi Standard Cobb-Douglas. Selain itu, manajer keluarga kurang produktif daripada manajer profesional. Oleh karena itu, penelitian ini merekomendasikan perusahaan keluarga untuk mempekerjakan manajer profesional guna meningkatkan produktivitas perusahaan. Sepengetahuan saya, ini adalah studi pertama yang menghubungkan antara kepemilikan keluarga dan produktivitas perusahaan di Indonesia, sehingga akan sangat membantu dalam pengembangan pengetahuan dalam topik yang diteliti yaitu hubungan kepemilikan keluarga dan produktivitas.
\end{abstract}

Kata kunci: Kepemilikan Keluarga; Perusahaan Keluarga; Manajer Keluarga; Manajer Profesional; Fungsi Produksi Cobb-Douglas 
Agency problems according to Jensen \& Mecking (1976) will arise when managers as agent manage the company not usually in accordance with the shareholders' interests as principal. However, such problems are less likely in the family firms, because managers generally come from family members who are also the firm's owners. Moreover, due to the presence of over-dominant family members in the family firm, it is likely to appear another agency model that is the gap between the majority shareholders from the family member who runs the company with the minority shareholders from external parties.

One definition explains that a company is considered as a family firm if two or more family members are directly involved in overseeing the company's finances (Anderson, Mansi, \& Reeb, 2003; Andres, 2008; Suyono, 2015). The family firm has a characteristic that can give advantages or disadvantages to the various parties involved in the firm. Barth, Gulbrandsen, \& Schøne (2005) analyzed the relationship between family ownership and firm productivity in managerial terms and concluded that family firms are less productive than non-family firms. The study considers that productivity differences are caused by the different regimes brought by each manager in managing the firm. Furthermore, about the decision in hiring the manager, whether the company will hire managers who come from the family members or hire professional managers. Barth, Gulbrandsen, \& Schøne (2005) concluded that in a family firm the hiring of professional managers would be more productive than the hiring of family managers.

Meanwhile, a study in the US corporations conducted by Anderson, Mansi, \& Reeb (2003) evaluated the relationship between family ownership and the agency cost of debt concluded that when the CEOs from family members lead the business, such condition precisely leads to higher cost of debt compared to when the CEOs from outside the family lead the business. Moreover, Andres
(2008) found that the performance of family firms is better than non-family firms only when the founding family members are still active in corporate management and the firm performance declines in the next generation. Similarly, Lodh, Nandy, \& Chen (2014) found that family ownership positively affects innovation by managers in the Indian listed companies and that innovation will increase when the family firms hire professional managers from non-family members.

Chen, Cheng, \& Dai (2007) examined the effect of family-owned firms in the US-listed corporations in addressing agency issues related to CEO turnover decisions and company performance. The study focused on three types of public companies in the US, namely: family firms with family CEO, a family firm with professional CEO, and non-family firms. The results concluded from the study are consistent with the initial predictions that there are many agency issues between family firms with family CEO and non-family firms in improving company performance and they prefer to hire professional CEOs in improving company performance.

Gedajlovic \& Carney (2010) evaluated why family businesses survive and what factors influencing the survival of family businesses in terms of industrial and geographical differences by using generic non-tradables identification (GNTs). Even though there are many types of industries in the family firms, they are able to posit the type of assets and combine them with generic non-tradables (GNTs), so that it can serve as the reason that family firms still get benefits from their business. Liu, Yang, \& Zhang (2012) also examined the extent to which the company's performance is owned by the family members and concluded that ownership concentration and family management affect the performance of the family firms.

Bennedsen et al. (2015) conducted a study on family firms in China and concluded that leadership succession within family firms in China is one form of adaptation of environmental opportunities 
in organizing family firms. Bertrand et al. (2008) studied 93 large corporations in Thailand and found a strong positive influence on the relationship between the percentage of family ownership and family involvement in corporate management and control within the family firms. On the other hand, Bunkanwanicha, Fan, \& Wiwattanakantang (2013) found that the proportion of shares owned by a group of family (family ownership) will increase when the company's partners come from a fellow family in Thailand corporations.

Sciascia \& Mazzola (2008) found empirical evidence in Italy that when family members intervene in corporate management, the company's performance will decrease. This finding is supported by subsequent studies in Italy conducted by Barbera \& Moores (2013) and Cucculelli et al. (2014). In line with findings in Italy, Burkart, Panunzi, \& Shleifer (2003) using the family ownership and ownership management model held by the owners of the company assumed a professional manager is better than a family manager in maintaining the balance of corporate income and protecting the firm's interests. King \& Santor (2008) conducted a study on the performance of family firms in 613 listed companies in Canada during 1998-2005 and found that family and non-family firms wherein the ownership structure had only a single share (common stock only) did not differ but for companies with multiple shares (common stock and preferred stock) then the performance of non-family firms is better than the family firms. Moreover, Caselli \& Di-Giuli (2009) found that family firms with non-family CFOs are better than those of family firms using family CFOs. Villalonga \& Amit (2010) found that when the company's founders and their families have strong control over companies, it can provide a competitive advantage for all shareholders. Barontini \& Bozzi (2010) examined CEO compensation and performance in family firms listed on the Italian Stock Exchange from 1998 to 2002 and showed that family firms pay their CEO better compared to other companies, and ownership structures have a significant influence on CEO compensation. Therefore, with a better CEO compensation in the family firms, it encourages a better firm performance.

Various previous studies documented that most companies in many countries prefer non-family managers rather than family managers to improve the company performance. Meanwhile, several previous studies in Indonesia also researched family firm issues such as Bambang \& Hermawan (2013), Diyanti, Widyawati, \& Husnah (2015), Singapurwoko (2015), Suyono (2016), and Oktavina, Manalu, \& Yuniarti (2018). Diyanti, Widyawati, \& Husnah (2015) concluded that family control through direct ownership could improve company performance through alignment effect and family control through indirect ownership with a pyramidal ownership structure undermines the company performance because it tends to generate the influence of absolute control (entrenchment effect). Another conclusion is that leadership of the company owner (family member) can improve the company performance in terms of alignment effect rather than entrenchment effect. So, the study concluded that the founder leadership is better in improving the company performance. Similar results are also presented in Singapurwoko (2015) which concluded that family ownership positively affects the firm performance as measured by ROA. Furthermore, Suyono (2016) using a sample of 112 firms listed on the Indonesia Stock Exchange for five years (2009-2013) concluded that family-controlled firms tend to perform better compared to non-family firms when financial performance is measured by an accounting measure (ROA) as well as a market measure (Tobin's Q).

On the other hand, Bambang \& Hermawan (2013) found that the performance of non-family firms is better than family firms as measured by ROA. Moreover, the ownership structure has a negative effect on the market valuation (Tobin's Q), and family members who have high positions in the company have a negative effect on the company performance. Furthermore, Bambang \& Hermawan (2013) argued that some family firms in Indonesia are 
framed under the name "foundations" to enable managers doing corruption and collusion activities that ultimately will degrade the company performance. Oktavina, Manalu, \& Yuniarti, (2018) showed that the average family firm in Indonesia still uses Pecking Order Theory in the application of capital structure.

The relationship between the variables in this study could be explained by the agency theory, where Jensen \& Meckling (1976) described the agency relationship between the owners as a principal and the managers as an agent. Moreover, the agency theory argues that in a modern corporation, in which the shareholding structure tends to spread, all managers' activities should be in order to maximize the stockbrokers' return (Berle and Means, 1932). The concept of this theory was begun with a change of relationship in managing a business, whereas the firm grows, the owners can no longer manage the firm directly. Therefore the owners will appoint independent parties as managers who will manage the company's daily activities. As a result, because managers govern the day-to-day company's activities, while the owners only receive reports from managers quarterly or annually, ultimately the managers have more knowledge on the details of the company activities than the owners. This condition raises asymmetric information between managers and owners, where managers with the superiority of information about the company often carry out actions for the sake of their personal interests that tend to harm the owners' interests. This model is further known as a type 1 agency problem which usually occurs in large corporations with spreading ownership structure.

The type 1 of agency problem as described by Jensen \& Meckling (1976) in the preceding paragraph disappears in the family firms with the dominance of shares' ownership on the hand of family members. However, Anderson, Mansi, and Reeb (2003) explained that although the type 1 of agency problem does not exist, it does not mean that there is no agency problem in the family firms. Thus, there will be another type of agency problem, from now on referred to as type 2 of the agency problem. This problem will arise when managers who are dominated by family members of majority shareholders prioritize their interests in the company's decisionmaking process that harms the interests of minority shareholders. It is because managers who come from the majority shareholdings often expropriate the minority shareholders' rights in managing corporate resources that could negatively affect the firm performance.

Moreover, the relationship between variables in this study can also be explained by using the stewardship theory from the side of the extent to which the parties concerned can evaluate the advantages and disadvantages of the family firm model. Stewardship theory developed by Donaldson \& Davis (1991) has a different perspective from agency theory when it comes to managers' role in the company. This theory assumes that managers are professional people appointed by shareholders to run the business, so their function is to serve the interests of shareholders in order to maximize their welfare. Given this theory, managers will feel satisfied when they are able to perform their function. In other words, under this theory, the managers will not behave opportunistically but instead, they will do the best job possible with maximum performance. This condition will be evident in family firms where managers generally come from the family members who control the majority of the company's shares, so they will maximize the use of company resources for the welfare of shareholders who are members of their family (Zellweger, Eddleston, \& Kellermanns, 2010; Berrone, Cruz, \& Gómez-Mejía 2012). However, other researchers have the opposite view of the benefits that family firms can turn out to be disadvantageous when there is a conflict of interest among family members due to distortions of incentives caused by kinship factors (GómezMejía et al., 2007; Lumpkin, Brigham, \& Moss, 2010; Cucculelli et al., 2014; Barbera \& Moores, 2013; Lodh, Nandy, \& Chen, 2014). In other words, the involve- 
ment of managers from the family members can lower the value of the firm.

In order to bridge the research gap as described above, this study uses the productivity as a proxy for the company performance. Palia \& Lichtenberg (1999) defined productivity as the ratio of output (real) to the input (real). The definition emphasizes more real output and input than output and nominal input in order to eliminate the effect of price changes when making productivity comparison. Because firm uses more than one input, there are several ways to determine the productivity. It is possible to determine the size of partial productivity, based only on a portion of the inputs used by the firm, as in labor productivity where it is calculated from the output per unit of labor divided by input per unit of labor (Palia \& Lichtenberg, 1999). However, Palia \& Lichtenberg (1999) and Barth, Gulbrandsen, \& Schøne (2005) argued that labor productivity is an imperfect measure of efficiency since it does not account for the output contribution of other non-collaborative inputs. Furthermore, Palia, \& Lichtenberg (1999) and Barth, Gulbrandsen, \& Schøne (2005) argued that a productivity measure that is able to show a good efficiency index and provide the appropriate weight for services of all inputs used by a firm is a Standard Cobb-Douglas production function. Following the views of Palia \& Lichtenberg (1999) and Barth, Gulbrandsen, \& Schøne (2005), this study uses the Standard Cobb-Douglas production function as a proxy of firm productivity besides no previous research in Indonesia that linked family ownership and firm productivity by using this proxy.

This study intends to re-examine the findings of previous studies in Indonesia that have conflicting results (Bambang \& Hermawan, 2013; Diyanti, Widyawati, \& Husnah, 2015; Singapurwoko, 2015; and Suyono, 2016) by further specifying the relationship between family ownership and company performance assessed by the firm productivity as measured by the Standard Cobb-Douglas production function, as well as further testing to evaluate the level of company productivity in different managerial systems (i.e., family managers and non-family managers). Moreover, to bridging the gap in the findings of previous studies in Indonesia, this study follows an argument stating that productivity can be used as a more accurate proxy in measuring company performance compared to financial performance as measured by accounting data such as ROE, ROI, ROA or market data such as Tobin's $Q$ for several reasons (Barth, Gulbrandsen, \& Schøne, 2005; Mannarino, Pupo, \& Ricotta, 2011). Firstly, unlike performance measures presented by external financial statements (i.e., ROE, ROI, and ROA) that are more easily manipulated by accountants, productivity is more difficult to manipulate because it reflects the company's internal performance that should be reported in a real condition (Palia \& Lichtenberg, 1999). Secondly, productivity is intrinsically able to determine the equilibrium value of financial variables, such as earnings and stock prices (Morikawa, 2013). Thirdly, market-based performance measures (Tobin's Q) can only be used accurately if the stock market is in the efficient condition (Brealey, Myers, \& Allen, 2016), which is not the case for the Indonesian Stock Exchange so this study argues that productivity as a performance measure will be more appropriate and accurate to measure the relationship between variables.

Based on existing literature, there is a research gap in previous studies examining the relationship between family ownership and company performance due to different proxies in measuring company performance. Various studies in Indonesia such as Diyanti, Widyawati, \& Husnah (2015), Singapurwoko (2015), and Suyono (2016) who found a positive relationship between family ownership and firm performance measured by ROA and Tobin's Q, while Bambang \& Hermawan (2013) found a negative relationship. However, when the measure of performance is firm productivity, the majority of previous studies abroad found a negative relationship between family ownership and firm productivity such as in Barth, Gulbrandsen, \& Schøne 
(2005), Bloom, Sadun, \& Van (2008); Bandiera et al. (2008); Mannarino, Pupo, \& Ricotta (2011), Barbera \& Moores (2013), and Cucculelli et al. (2014).

Based on the research gap as explained above, this study tries to examine the relationship between family ownership and firm productivity. Therefore, this study aims to examine the effect of family ownership on the firm productivity, differentiation of firm productivity levels with different managerial systems between family managers and professional managers, and examine whether the family firms are better to hire family managers or professional managers.

\section{HYPOTHESES DEVELOPMENT}

From a theoretical point of view, the influence of family management on corporate performance remains an interesting issue. There are many conflicting ideas that ultimately encourage researchers to test the relationship between these variables. Empirical evidence also does not provide a similar answer. Some studies have examined the impact of family influence on company performance, and the results are divided into the view that concentrated family ownership and management of the firm by the owner may have beneficial economic consequences or otherwise. Therefore, some empirical evidence suggests that family firms are more profitable or show higher market valuations when management is handled by the founder (Martikainen, Nikkinen, and Vahamaa, 2009). In contrast, some researchers found that firms with family ownership have lower economic performance than non-family firms (Caselli \& Di-Giuli, 2009; Sciascia \& Mazzola, 2008; Chaney, Faccio, \& Parsley, 2011; Barbera \& Moores, 2013; Cucculelli et al., 2014).

Several previous studies in Asia, including Indonesia, concluded that the corporate sector in these countries is dominated by family-owned companies (Gul, Kim, \& Qiu, 2010) with relatively weak corporate governance practices (Chaney, Faccio, \& Parsley, 2011). Direct monitoring and substantial control by the family is considered an agency problem that can lead to different corporate disclosure practices between family and non-family firms (Chaney, Faccio, \& Parsley, 2011). On the other hand, some studies have found that negative effects will arise when the next generation within the family firms runs the business and found that family firms with family managers run the business with worse performance (Caselli \& Di-Giuli, 2009; Sciascia \& Mazzola, 2008).

As for previous studies abroad linking family ownership to productivity, it generally results in a negative relationship between family ownership and productivity. For the case in Norway, Barth, Gulbrandsen, \& Schøne (2005) documented a negative relationship between family management and firm productivity as measured by the Standard Cobb-Douglas production function. Bloom, Sadun, \& Van (2008) showed that Italian entrepreneurs are reluctant to formally hand over the management of the company to managers from outside parties that ultimately reduce the firm productivity. Furthermore, Bandiera et al. (2008) confirmed these findings. Similar results also occurred in Mannarino, Pupo, \& Ricotta (2011) which found that family firms are significantly less productive, as measured by total factor productivity (TFC) than non-family firms. Subsequent studies in Italy (Barbera \& Moores, 2013; Cucculelli et al., 2014) also corroborated these findings. The relatively recent findings in Italy also confirmed that the productivity of family firms is much lower than those of the non-family firms (Damieni, Pompei, \& Ricci, 2016). Furthermore, for the case in Japan Morikawa (2013) reported that the productivity of family firms is worse than nonfamily firms.

This study is more likely to use theory agency in the context of family firms as described by Anderson, Mansi, and Reeb (2003) which states that the presence of over-dominant family members in the company can create an entrenchment effect that can negatively affect the company performance. It is because with the dominance of shares ownership, 
they can take the minority shareholders' rights to prioritize the group of family interests so that family firms dominated by family managers generally have a poor performance (Caselli \& Di-Giuli, 2009; Sciascia \& Mazzola, 2008; Lumpkin, Brigham, \& Moss, 2010). Furthermore, the majority of previous studies found a negative relationship between family ownership and performance as measured by firm productivity (Barth, Gulbrandsen, \& Schøne, 2005; Bloom, Sadun, \& Van, 2008; Bandiera et al., 2008; Mannarino, Pupo, \& Ricotta, 2011; Morikawa, 2013; Barbera \& Moores, 2013; Cucculelli et al., 2014; and Damieni, Pompei, \& Ricci, 2016). Therefore, based on entrenchment effect argument in the agency theory and majority findings of previous studies as explained above, the first hypothesis is developed as follows:

$\mathrm{H}_{1}$ : family ownership affects negatively on the firm productivity

With regard to the difference between managers from the group of family (i.e., family managers) and managers from outside parties (professional managers), the agency theory predicts the positive impact of the owner's management on the value of the firm, as the owner's management is able to align the interests of owners and managers (Jensen \& Mechling, 1976). However, this effect may decrease with the cost of family management. Family managers are generally not recruited from the general market for managers, and this situation generally leads to lower quality among owner managers rather than professional managers because the recruitment procedures do not follow certain qualification standards. Commonly, the recruitment of managers from the family members is only based on the close relationship among family member without considering relevant expertise to his/her job, so that when the quality of managers from the family members is low, automatically will reduce the firm productivity. Moreover, family-owned firms tend to be characterized by caution in strategic decision making, because of the close relationship between family and company assets (Barth, Gulbrandsen, \& Schøne, 2005). This avoidance of risk can prevent the owners' management from adopting contemporary management concepts in increasing productivity because it is too risky or violates the family business tradition. Ultimately, this condition contributes to reducing the whole company productivity.

Other studies that focus on the effect of founder leadership on the firm performance provide mixed results. Cucculelli \& Micucci (2008) found a positive founder effect on firm performance followed by the decline of firm performance in the postleadership succession in the family firms in Italy. It indicates that the family managers are only good at the beginning of the company's establishment and becomes worse for the subsequent periods. Bloom, Sadun, \& Van (2008) described that Italian entrepreneurs are reluctant to formally hand over corporate management to outsiders and this may have low productivity implications. In an analysis of how managers are employed and incentives are offered, Bandiera et al. (2008) confirmed these findings.

Furthermore, other researchers suggested that many beneficial attributes can be a disadvantage since conflicts of interest in the family firms can distort incentives because of kinship behavior (GómezMejía et al., 2007; Lumpkin, Brigham, \& Moss, 2010). Barth, Gulbrandsen, \& Schøne (2005) compared family businesses managed by family members of owners and family businesses run by professional managers and found that family firms managed by professional managers are more productive than those family firms managed by family managers. Caselli \& Di-Giuli (2009) and Sciascia and Mazzola (2008) found that family firms with family managers run company with worse performance.

Burkart, Panunzi, \& Shleifer (2003) argued that the appointment of family managers who generally is done without considering certain skill or expertise will lead to the low quality of managers who can harm the company productivity. Furthermore, Mannarino, Pupo, \& Ricotta (2011) who researched family firms in Italy found that professional man- 
agers are more efficient in operating firms than owner-managers. Similarly, Lodh, Nandy, \& Chen (2014) suggested that family firms better hire professional managers in order to further enhance the innovations made by managers.

Based on the arguments built from the findings of previous studies stating that professional managers are more productive than family managers, therefore the second and third hypotheses in this study are formulated as follows:

$\mathrm{H} 2$ : professional managers are more productive in managing a business than family managers.

H3: family firms would be better to hire professional managers than family managers

\section{METHODS}

This study uses a sample of all companies listed on the Indonesia Stock Exchange for 2011 to 2015 periods. Moreover, this study implements purposive sampling approach in the sample selection with criteria as in Table 1.

This study follows several criteria used in previous studies (Barth, Gulbrandsen, \& Schøne, 2005; Mannarino, Pupo, \& Ricotta, 2011; Barbera, 2013; Suyono, 2015) as follows, if 33\% or more shares in the company are owned by one person or one family (group), then classified as a family firm. Meanwhile, if the condition is not met it is classified as a non-family firm.

If there are $>2$ managers who come from the family members then the company is classified as a company that uses the family managers, whereas if there is only one manager or none of the managers who come from the family members, it means that the company uses professional managers.

This study uses Standard Cobb-Douglas production functions modified by Barth, Gulbrandsen, \& Schøne (2005) and Barbera (2013) to calculate the extent to which productivity differences existed in the presence of different ownership structures between family firms and nonfamily firms. In this case, Barth, Gulbrandsen, \& Schøne (2005) and Barbera (2013) included the variable family ownership structure (FAM) with the following formula:

$\mathrm{Y}=\mathrm{A}^{\gamma \mathrm{FAM}} \mathrm{L}^{\alpha} \mathrm{K}^{\beta}$

Where:

Y : Value-added reflecting Standard CobbDouglas production function

A : Total Factor Productivity

$\gamma \quad$ : the intercept indicating whether family firms are more productive (indicated with a positive sign) or less productive (indicated with a negative sign) compared to nonfamily firms.

$\alpha \quad$ : The output of labor elasticity which is the proportion of labor to the total product produced.

$\quad \beta \quad$ : The output of capital elasticity which is the proportion of capital to the total product produced

L : Labour

K : Capital

FAM : a dummy variable, where score 1 is given to the family firms and 0 is given to the nonfamily firms.

Table 1. Sampling Procedure

\begin{tabular}{lr}
\hline \multicolumn{1}{c}{ Criteria of Sample } & Amount \\
\hline Listed companies on the Indonesian Stock Exchange for 2011-2015 periods & 535 \\
Listed companies with an incomplete annual report & $(150)$ \\
Listed companies without purchasing of intermediary goods or raw material and excluding corporations in & $(233)$ \\
the financial, trading, and investment sectors & $(8)$ \\
Listed companies with incomplete data related the proxies of variables in this study & 144 \\
Total Sample & 720 \\
Number of observations for 5 years (2011-2015)
\end{tabular}


Labor (L) is generated by calculating the number of labors in the company (available in the annual report). Capital (K) is calculated by adding the company's equity and debt.

Furthermore, by following the model developed by Barth, Gulbrandsen, \& Schøne (2005) and Barbera (2013) in measuring the importance of ownership structure, this study included the FAM as a dummy variable. Therefore, by taking the logarithm of the production function, the equation is as follows:

$\operatorname{Ln} Y=\ln A+\gamma F A M+\alpha \ln L+\beta \ln K$

Where (after controlling all observable variables) $\gamma$ is the intercept that measures whether family firms are more or less productive than non-family firms.

In contrast to Barth, Gulbrandsen, \& Schøne (2005) who used two control variables (i.e., type of industry and stock exchange), this study uses only one control variable, i.e., type of industry. Stock exchange as a control variable is excluded because not relevant for the setting of this study which only uses listed companies on the Indonesia Stock Exchange as the population. The type of industry as a control variable is a dummy variable which is measured by following the categorization by the Indonesia Stock Exchange which divides the type of industry into the main sector (IN1), manufacturing sector (IN2), and service sector (IN3). Therefore, the type of industry is measured by dummy variables in which a score of 1 is given when the firm is in its industrial sector and 0 if otherwise. Morover, Following Gujarati and Porter (2009) who argued that if dummy has a category of $\mathrm{m}$, then one category will be excluded so that the number of dummy variables becomes $\mathrm{m}-1$. Therefore, since the type of industry has 3 categories, it will remain 2 (3-1) in the model.

In other words, by Following Barth, Gulbrandsen, \& Schøne (2005) except for the stock exchange as a control variable due to not relevant for this study, to test the first hypothesis stating that family ownership negatively affects firm's productivity, OLS is used with three research models as follows:

Model 1: This model uses family ownership (OS_FAM) and the number of labors (L) as independent variables and type of industry as a control variable. Then, Model 1 is presented as follows:

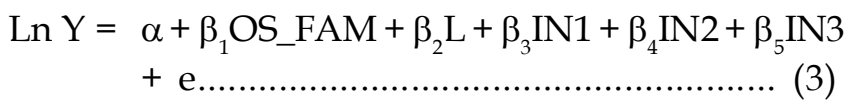

Model 2: This model uses family ownership (OS_FAM), family manager (FAM_MAN), and the number of labors (L) as independent variables and type of industry as a control variable. Then, Model 2 is described as follows:

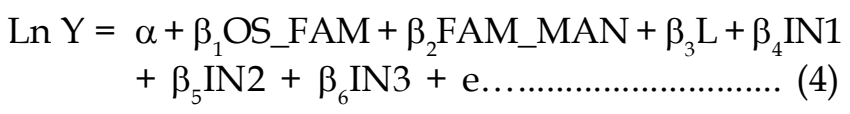

Model 3: This model uses family ownership (OS_FAM), family manager (FAM_MAN), number of labors (L), and capital (K) as independent variables and type of industry as a control variable. Then, Model 3 is formulated as follows:

$$
\begin{aligned}
\text { Ln Y }= & \alpha+\beta_{1} \text { OS_FAM }+\beta_{2} \text { FAM_MAN }+\beta_{3} \mathrm{~L}+\beta_{4} \mathrm{~K} \\
& +\beta_{5} \mathrm{IN} 1+\beta_{6} \mathrm{IN} 2+\beta_{7} \mathrm{IN} 3+\mathrm{e} \ldots \ldots \ldots \ldots \ldots \ldots . . . . .
\end{aligned}
$$

Where:

Ln Y: logarithm of production function

Moreover, to test the second hypothesis stating that professional managers are more productive in managing a business than family managers, this study determines the range of productivity differences in the use of family managers and professional managers. It could be seen from the production elasticity which is calculated by using two inputs of variables, i.e., labor (L) and capital (K) such in the model 3, with the following formula (Barth, Gulbrandsen, \& Schøne, 2005; and Barbera, 2013): 
$\mathrm{Q}=\mathrm{b}_{0} \mathrm{~L}^{\mathrm{b} 1} \mathrm{~K}^{\mathrm{b} 2}$

Where:

Q : The elasticity of the production function

$\mathrm{b}_{0} \quad$ : The Efficiency Index (the intercept in the model 3)

$\mathrm{b}_{1} \quad$ : Parameter L (regression coefficient of $\mathrm{L}$ in the model 3)

$b_{2}$ : Parameter $K$ (regression coefficient of $K$ in the model 3)

L : number of labors

K : capital

The second hypothesis testing is done by looking at the difference in the elasticity of the production function which describes the difference in productivity range between family firms hiring family managers and family firms hiring professional managers. This hypothesis will be accepted if the productivity range of professional managers is higher than the family managers.

Furthermore, to test the third hypothesis which states that family firms would be better to hire professional managers than family managers, additional analysis is needed to recommend whether family firms will be better to hire family managers or professional managers in corporate management. Following Barth, Gulbrandsen, \& Schøne (2005) and Barbera (2013), this study adds several control variables such as the number of labors, capital, type of industry, and the return of capital as described in table 7 on the section of research result.

\section{RESULTS \\ Descriptive Statistic}

Table 2 above explains that the number of family firms is larger than nonfamily firms in the Indonesian Stock Exchange, i.e., from 720 observations, 475 observations are family firms (i.e., $65.97 \%$ ) and 245 observations are nonfamily firms (i.e., 34.03\%). Moreover, from 475 observations of family firms, 220 observations (i.e., $46.32 \%$ ) hire managers from family members while the remaining 255 observations (i.e., 53.68\%) hire managers from independent/professional parties. This empirical evidence suggests that family-controlled firms in the Indonesia Stock Exchange hire more professional managers than family managers.

This study measures whether a firm to be considered as family firm or nonfamily firm by using a binary variable when OS_FAM $=1$ is family firm,

Table 2. Descriptive Statistic

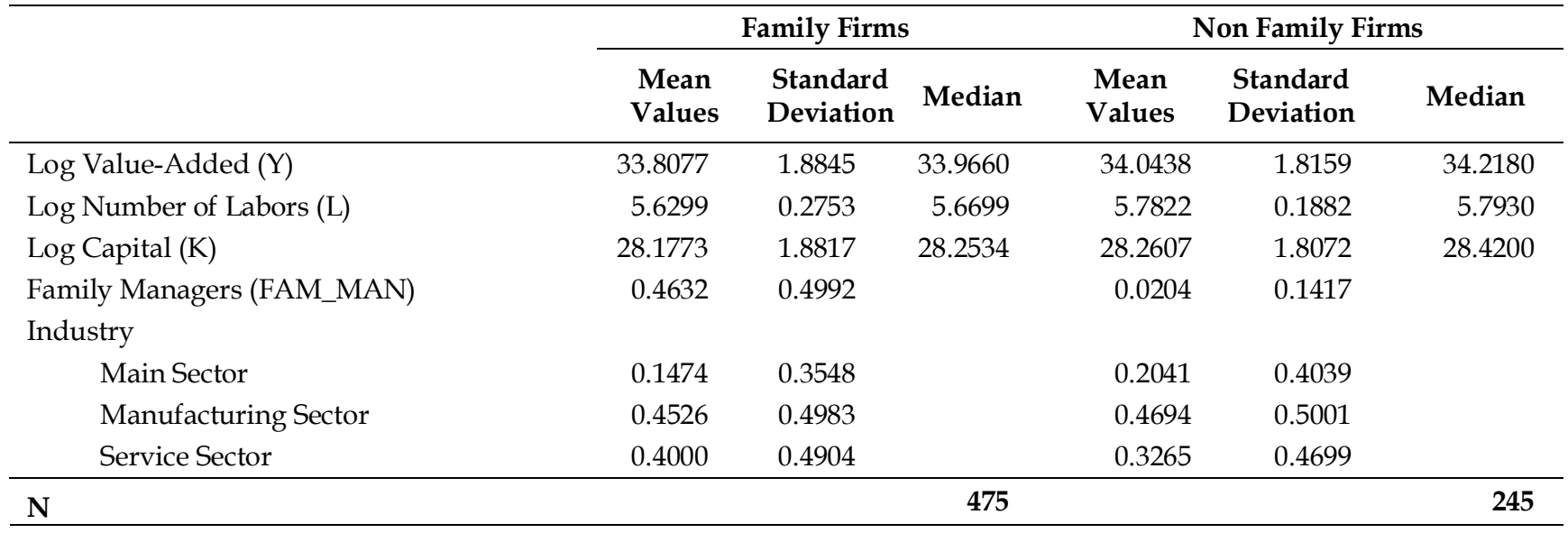


otherwise is nonfamily firm (OS_FAM = 0). Following Barth, Gulbrandsen, \& Schøne (2005), then the equation for a $\log$ of the production function is presented as follows:

$\operatorname{Ln} Y=\ln A+\gamma F A M+\alpha \ln L+\beta \ln K$

Moreover, the equation of the production function is then explained through the three models which have differences in function due to additional control variables in each model.

Before regression analysis, a classical assumption test was performed for all three models including normality, heteroscedasticity, and multicollinearity. Moreover, the homogeneity test is also conducted to ascertain that the variations of two or more distributions have similarity or not. Then, this study runs multiple regression analysis for the three models, and the summary of the results is presented in Table 3 .

Table 3 above presents a summary of the results of regression analysis, where the dummy vari- able of the type of industry for manufacturing sector (IN2) is excluded from the model. Therefore, the rest of type of industry variables are the main sector (IN1) and the service sector (IN3). Then, the regression equation for the three models is presented as follows:

Model 1

$\begin{aligned} \operatorname{Ln} Y= & 29.985-0.135 \text { OS_FAM }+0.688 \mathrm{~L}+0.145 \\ & \text { IN } 1+0.163 \mathrm{IN} 3+\mathrm{e}\end{aligned}$

Model 2

$\begin{aligned} \text { Ln } Y= & 29.103-0.218 \text { OS_FAM + 0.244 FAM_MAN } \\ & +0.840 \mathrm{~L}+0.151 \mathrm{IN} 1+0.144 \mathrm{IN} 3+\mathrm{e}\end{aligned}$

Model 3
Ln $Y=0.108-0.101$ OS_FAM + 0.201 FAM_MAN $+1187.286 \mathrm{~L}+9603.505 \mathrm{~K}+0.301 \mathrm{IN} 1+0.601$ IN3 + e

Furthermore, $\mathrm{F}$ test is performed for the above three models as in Table 4 .

Table 3. The Output of Regression for the Three Model

\begin{tabular}{|c|c|c|c|}
\hline & Model 1 & Model 2 & Model 3 \\
\hline \multirow{2}{*}{ Intercept } & 29.985 & 29.103 & .108 \\
\hline & $(0.000)$ & $(0.000)$ & $(0.150)$ \\
\hline \multirow[t]{2}{*}{ Family firms } & -.135 & -.218 & -.101 \\
\hline & $(0.037)$ & $(0.018)$ & $(0.013)$ \\
\hline \multirow{2}{*}{ Family Managers } & & .244 & 0.201 \\
\hline & & $(0.177)$ & $(0.576)$ \\
\hline \multirow[t]{2}{*}{ Log number of labors } & .688 & .840 & 1187.286 \\
\hline & $(0.015)$ & $(0.006)$ & (0.000) \\
\hline \multirow[t]{2}{*}{ Log Capital } & & & 9603.505 \\
\hline & & & (0.000) \\
\hline \multicolumn{4}{|c|}{ Industry (ref: Manufacturing) } \\
\hline \multirow[t]{2}{*}{ Main Sector } & .145 & .151 & .301 \\
\hline & $(0.470)$ & $(0.461)$ & $(0.757)$ \\
\hline \multirow[t]{2}{*}{ Service Sector } & .163 & .144 & 0.217 \\
\hline & $(0.286)$ & $(0.323)$ & $(0.618)$ \\
\hline $\mathrm{R}^{2}$ adj. & 0.007 & 0.009 & .601 \\
\hline $\mathbf{N}$ & 720 & 720 & 720 \\
\hline
\end{tabular}

Estimates of the production function including indicators of family ownership (Model1), family management (Model 2), and capital (Model 3). Estimated coefficients and standard errors of coefficients in parentheses. Ordinary Least Squares.Dependent variable: Log Value Added. 
Table 4 above shows the $\mathrm{R}$ Square for the model 1 , model 2 , and the model 3 is $1.3 \%$; $1.5 \%$; and $70 \%$, respectively. The R Square of the model 1 and the model 2 is relatively small then jumps significantly in the model 3 . It is because the model 1 and 2 do not include the Capital in calculating the production function, whereas when the Capital is included in the model 3, then there is a significant change on the R Square. Thus it can be concluded that the measurement of productivity will not be optimum when the element of Capital is not included the model.

Based on the $\mathrm{F}$ test above, it can be concluded that: (1) Ffor the first model, the F-statistic of 3.345 on the significance of 0.049 means that the first model is fit in explaining the relationship between variables in this study. (2) For the second model, F-statistic of 3.243 on the significance of 0.038 means that the second model is fit to explain the relationship between variables in this study. (3) For the third model, the F-statistic of 5.611 on the significance of 0.000 means that the third model is fit to explain the relationship between the variables in this study.
Based on the above tests, the three models are fit because the results of F-statistic are below 0.05 and it could be concluded that: (1) family ownership negatively affects the firm productivity. (2) Managers who come from the family members do not affect the firm productivity. (3) The number of labors has a significant positive influence on the firm productivity. (4) Capital has a significant positive influence on the firm productivity. (5) The type of industry has no significant influence on the firm productivity (for both the main sector and the service sector). (6) From the results of all testing, it can be concluded that the first hypothesis is stating that family ownership negatively affects productivity is supported.

Model 1 in table 3 above generally also shows that family firms are lower in the range of productivity compared to non-family firms. Model 2 is controlled by the variable of family managers (FAM_MAN). The family firms with less productive family managers than nonfamily firms. These results indicate the differences in management regimes in running the business, especially in the as-

Table 4. The Summary of F-test

\begin{tabular}{lcccc}
\hline & F & Sig. & R Square & Adj R Square \\
\hline Model 1 & 3.345 & 0.049 & 0.013 & 0.007 \\
Model 2 & 3.243 & 0.038 & 0.015 & 0.009 \\
Model 3 & 5.611 & 0.000 & 0.701 & 0.601 \\
\hline
\end{tabular}

Table 5. The Elasticity of Production

\begin{tabular}{lccccc}
\hline & R Square & $\begin{array}{c}\text { Adj. R } \\
\text { Square }\end{array}$ & Nilai F (Sig) & Nilai t (Sig) & Sample \\
\hline FAM_MAN = 1 & 0.801 & 0.701 & $7.872(0.000)$ & $88724.849(0.000)$ & 220 \\
FAM_MAN = 0 & 0.801 & 0.701 & $8.433(0.000)$ & $91833.969(0.000)$ & 255 \\
\hline
\end{tabular}

Dependent variable: Log Value-Added (Y). Independent Variable: Elasticity of Productivity (Q)

The result of regression calculation in model 3 using two input variables: L (Labor) and K (Capital).

Table 6. The Range of Productivity between Family Managers and Professional Managers (\%)

\begin{tabular}{lr}
\hline The range of productivity by using one input variable $(\mathrm{L}) * * *$ & 9 \\
The range of productivity by using two input-variables $(\mathrm{L} \text { and } \mathrm{K})^{* * *}$ & 3.5 \\
The total range of productivity & 12.5 \\
\hline
\end{tabular}

*** The range of productivity by using one input-variable comes from model 1, meanwhile, two input-variables from model 3. 
pect of firm productivity. The addition of capital in the model 3 improves a negative effect on the model because the regression coefficient of the family manager in the model 3 decreases by 0.043 from the number 0.244 (in the model 2) to 0.201 with significance value more than 0.05 . Furthermore, from table 3 above, it can be concluded that the variable of a number of labors and capital adequately explain the level of firm productivity between family firms and nonfamily firms.

Moreover, to test the second hypothesis in determining the range of productivity differences in the use of family managers and professional managers, this study uses the elasticity of production. The elasticity of production is calculated by using two input variables, i.e., labor (L) and Capital (K) in the model 3 following Barth, Gulbrandsen, \& Schøne (2005) and Barbera (2013) as follows:

$\mathrm{Q}=\mathrm{b}_{0} \mathrm{~L}^{\mathrm{b} 1} \mathrm{~K}^{\mathrm{b} 2}$

Where:

Q: The elasticity of the production function

$b_{0}$ : The Efficiency Index (the intercept in the model 3)

$b_{1}$ : Parameter $L$ (regression coefficient of $L$ in the model 3)

$\mathrm{b}_{2}$ : Parameter $\mathrm{K}$ (regression coefficient of $\mathrm{K}$ in the model 3)

L: number of labors

K: capital

Based on the above formula, the value of production elasticity for each company and the results of the analysis can be seen in Table 5 .

Based on Table 5 above, the number of observations used is 475 (i.e., family firms only), which is divided into two more criteria that are family firms with family managers (FAM_MAN $=1$ ) and family firms with professional managers $($ FAM_MAN $=0)$. The Adjusted R Square is 0.701 means that $70 \%$ of independent variables properly explain the dependent variable. The F-statistic increases by 0.561 from 7.872 to 8.433 , meanwhile, $t$ statistic also increases 3109.12 from 88724.849 to 91833.969. It means that the difference in the elasticity of production function describing the difference of the firm productivity range between the family firms hiring family managers and professional managers is $12.5 \%$. In other words, the productivity of professional managers is $12.5 \%$ higher than family managers. The detailed calculation of the range of productivity is presented in Table 6 .

The results presented in Table 5 and 6 above also support the second hypothesis stating that professional managers are more productive than family managers. Furthermore, additional test is performed to assess the strength of the test by including some control variables such as those of Barth, Gulbrandsen, \& Schøne (2005) as well as to provide recommendations to the family firms on the managerial choices that could increase the productivity of the firm whether better to hire family managers or professional managers. Then the test is performed on two group of samples, i.e., the entire sample of the firms (720 observations) and the sample for the family firms only (475 observations). The results are presented in table 7 .

In Table 7 above, several alternative models are employed in the regression analysis by separating the sample between All Firms criteria using all observations (720) and Family-Owned Firms criteria using family firms' observations (475). By entering several control variables such as in Barth, Gulbrandsen, \& Schøne (2005) and excluding the sub-sample of non listed firms because not relevant for this study which uses only companies listed on the Indonesia Stock Exchange as a sample. Then, Table 7 above shows several specifications and concludes that there are only eight specifications that have a significant influence by looking at a significance value which is less than 0.05 . The use of dependent variable Ln Value Added/Unit of Capital as a substitute for the previous dependent variable 
(Ln Value Added) gives significant negative effect (sig. $=0.000$ ), which can be described as follows: (1) manager who comes from the family members on all firms (720 observations) has a significant negative effect on company productivity. It means that the use of managers who come from the family members will actually reduce the level of firm productivity. (2) Family ownership has a significant negative effect on company productivity. It means that by increasing the number of ownership by family members lower the level of firm productivity. This finding supports the first hypothesis which

Table 7. Alternative Specifications and Robustness Check

\begin{tabular}{|c|c|c|c|c|c|}
\hline \multirow{2}{*}{\multicolumn{2}{|c|}{ Alternative Specifications }} & \multirow[b]{2}{*}{$\begin{array}{l}\text { Number of } \\
\text { observations }\end{array}$} & \multicolumn{2}{|c|}{ All firms } & \multirow{2}{*}{$\begin{array}{c}\text { Family-owned firms } \\
\begin{array}{c}\text { Managers from owne } \\
\text { family }\end{array}\end{array}$} \\
\hline & & & $\begin{array}{c}\text { Managers from } \\
\text { owner family }\end{array}$ & $\begin{array}{c}\text { Family } \\
\text { Ownership }\end{array}$ & \\
\hline \multicolumn{2}{|r|}{$\begin{array}{l}\text { Dependent variable: Ln Value-added } \\
\text { per unit of capital }\end{array}$} & $720 / 475$ & $\begin{array}{r}-13.420 \\
(0.000)\end{array}$ & $\begin{array}{l}-7.800 \\
(0.000)\end{array}$ & $\begin{array}{l}-9.363 \\
(0.000)\end{array}$ \\
\hline \multirow{2}{*}{\multicolumn{2}{|c|}{$\begin{array}{l}\text { Dependent variable: Total Factor } \\
\text { productivity } \\
\text { Dependent variable: Ln Sales }\end{array}$}} & $720 / 475$ & $\begin{array}{c}0.462 \\
(0.644)\end{array}$ & $\begin{array}{l}1.348 \\
(0.178)\end{array}$ & $\begin{array}{l}1.731 \\
(0.084)\end{array}$ \\
\hline & & $720 / 475$ & $\begin{array}{c}0.511 \\
(0.610)\end{array}$ & $\begin{array}{l}-0.263 \\
(0.793)\end{array}$ & $\begin{array}{c}0.496 \\
(0.620)\end{array}$ \\
\hline \multirow{2}{*}{\multicolumn{2}{|c|}{$\begin{array}{l}\text { Alternatif forms of labor input } \\
\text { Number of labors replaced by payroll } \\
\text { cost } \\
\text { Hourly wage added to number of } \\
\text { labors }\end{array}$}} & $720 / 475$ & $\begin{array}{c}2.186 \\
(0.029)\end{array}$ & $\begin{array}{c}0.543 \\
(0.587)\end{array}$ & $\begin{array}{l}1.670 \\
(0.096)\end{array}$ \\
\hline & & $720 / 475$ & $\begin{array}{l}0.254 \\
(0.800)\end{array}$ & $\begin{array}{l}0.484 \\
(0.629)\end{array}$ & $\begin{array}{c}0.130 \\
(0.897)\end{array}$ \\
\hline \multicolumn{6}{|c|}{$\begin{array}{l}\text { a. Subsamples } \\
\text { Number of labors }\end{array}$} \\
\hline & a. less than 200 labors & $65 / 60$ & $\begin{array}{l}-0.735 \\
(0.465)\end{array}$ & $\begin{array}{l}0.800 \\
(0.936)\end{array}$ & $\begin{array}{l}-0.792 \\
(0.432)\end{array}$ \\
\hline & b. 200 labors or more & $655 / 415$ & $\begin{array}{c}0.334 \\
(0.738)\end{array}$ & $\begin{array}{l}-1.332 \\
(0.183)\end{array}$ & $\begin{array}{c}0.943 \\
(0.346)\end{array}$ \\
\hline \multirow[t]{3}{*}{$\mathrm{b}$} & Capital & & & & \\
\hline & 10 billion Rupiah or more & $138 / 91$ & $\begin{array}{l}-0.104 \\
(0.918)\end{array}$ & $\begin{array}{l}-0.993 \\
(0.323)\end{array}$ & $\begin{array}{c}0.609 \\
(0.544)\end{array}$ \\
\hline & Less than 10 billion Rupiah & $582 / 384$ & $\begin{array}{l}-1.657 \\
(0.098)\end{array}$ & $\begin{array}{l}-1.939 \\
(0.053)\end{array}$ & $\begin{array}{l}-1.058 \\
(0.291)\end{array}$ \\
\hline \multirow[t]{4}{*}{ c } & Industry & & & & \\
\hline & Main Sector & $82 / 41$ & $\begin{array}{l}-0.847 \\
(0.400)\end{array}$ & $\begin{array}{l}-2.084 \\
(0.040)\end{array}$ & $\begin{array}{l}-0.174 \\
(0.862)\end{array}$ \\
\hline & Manufacturing & $210 / 124$ & $\begin{array}{l}1.137 \\
(0.257)\end{array}$ & $\begin{array}{l}-0.761 \\
(0.448)\end{array}$ & $\begin{array}{l}1.267 \\
(0.208)\end{array}$ \\
\hline & Services & $177 / 109$ & $\begin{array}{l}-1.337 \\
(0.183)\end{array}$ & $\begin{array}{l}-0.023 \\
(0.981)\end{array}$ & $\begin{array}{l}-1.438 \\
(0.153)\end{array}$ \\
\hline \multirow[t]{3}{*}{ d } & $\begin{array}{l}\text { Return of capital } \\
\text { Dependent variable }\end{array}$ & & & & \\
\hline & $\begin{array}{l}\text { Value-added divided by total } \\
\text { capital }\end{array}$ & $720 / 475$ & $\begin{aligned}-13.291 \\
(0.000)\end{aligned}$ & $\begin{array}{l}-7.169 \\
(0.000)\end{array}$ & $\begin{array}{l}-9.768 \\
(0.000)\end{array}$ \\
\hline & 2 Return divided by total capital & $720 / 475$ & $\begin{array}{c}1.419 \\
(0.156)\end{array}$ & $\begin{array}{c}0.725 \\
(0.469)\end{array}$ & $\begin{array}{c}1.015 \\
(0.311)\end{array}$ \\
\hline
\end{tabular}

Dependent variable: Log value-added.

Return on Capital is regressed on the type of industry and family control variables only. Estimated coefficients and standard errors. Level significance at $5 \%$ 


\section{Jurnal Keuangan dan Perbankan | KEUANGAN}

Vol. 22, No. 2, April 2018: 256-275

states that family ownership negatively affects the firm productivity. (3) Managers who come from family members in the family firms (475 observations) have a significant negative effect on the firm productivity. Similar to the first case, however, on this setting, the sample is more emphasized on the ownership by family members in the family firms only that still hire non-professional managers (managers from the family members). The results show the decline in the quality of firm productivity in line with the increasing use of family managers.

Table 7 above also presents some control variables that have a significant influence on firm productivity. Suppose the specification on the input labor that is by replacing the independent variable number of labors with payroll cost. There is a significant positive correlation (sig value $=0.029$ ) resulting from the use of variable payroll cost on company productivity in firms using nonprofessional managers for all firms (720 observations). Thus, it is concluded that with the increase of salary cost incurred by non-professional managers (i.e., family managers) then the firm productivity will increase, otherwise if the cost of salary is lowered it will lower the level of firm productivity. Furthermore, there is evidence that increased productivity is not due to professional or non-professional managers, but more to the increase in salaries received by labors so that they will continue to improve their performance that will ultimately increase the firm productivity. Table 7 above also indicates that the industry specification for the type of industry in the main sector of the family business has a significant negative effect on firm productivity.

Then, on the specification of return of capital which replaces the previous dependent variable by dividing the value-added with total capital also produces a significant negative effect. It is similar to the previous results above, where productivity decreases when the variable control of return of capital as in the above table increases. Moreover, the rest of control variables do not affect the firm productivity.
Ultimately, the results as shown in Table 5 and 6 , and supported by the results in Table 7 above conclude that professional managers are more productive than family managers. Thus the third hypothesis which states that family firms prefer to hire professional managers rather than family managers is supported.

\section{DISCUSSION}

The first hypothesis in this study states that family ownership negatively affects the firm productivity. The results of the analysis in this study support the first hypothesis where the regression output shows that family-owned firms are less productive than nonfamily-owned firms. It means that the existence of family ownership within a company tends to decrease the firm productivity as measured by the Standard Cobb-Douglas production function. In other words, the greater the proportion of shares owned by the family members will further decrease the firm productivity. These findings support the argument stating that negative effects will arise when the next generation of the family in the firm runs the business, so the bigger and longer family shares ownership in the firm will decrease the firm productivity as revealed by Cucculelli \& Micucci (2008). It is because there is a tendency that when the shares owned by family members is so dominant, the concept in the agency theory which states that the dominant role of family members in managing the firm will create an entrenchment effect that will encourage the owner from the family members to take the rights of minority shareholders for the benefit of their group which will ultimately reduce the company's performance (Anderson, Mansi, \& Reeb, 2003). The findings of this study also support the arguments from Gómez-Mejía et al. (2007) and Lumpkin, Brigham, \& Moss (2010) where the conflict of interest among family members can distort incentives due to kinship behavior in the firm's management that ultimately can reduce the firm productivity. 


\section{Family Involvement in Firm's Management and Productivity: An Empirical Evidence from Indonesia}

Eko Suyono

These findings are in-line with Caselli \& DiGiuli (2009), and Sciascia and Mazzola (2008) who found that family firms generally led by managers from family members tend to have lower productivity than non-family firms generally led by professional managers. The findings in this study are also in-line with Barth, Gulbrandsen, \& Schøne (2005) who found that the productivity rate in family-owned enterprises is lower than non-family enterprises with an estimated difference of $10 \%$. Similar findings are also found in Bloom, Sadun, \& Van (2008), Bandiera et al. (2008), and Mannarino, Pupo, \& Ricotta (2011) who found that firms with dominant family shareholdings in Italy tend to be reluctant to hand over corporate leadership to non-family entities so that productivity is worse than nonfamily firms led by professional managers from external parties. Furthermore, the results of this study also confirm the findings of Morikawa (2013) in Japan and Cucculelli et al. (2014); Barbera \& Moores (2013); and Damieni, Pompei, \& Ricci (2016) in Italy stating that the productivity of family businesses is far below non-family businesses.

Furthermore, the second hypothesis states that professional managers are more productive in running a business than family managers. The findings in this study also support the hypothesis. The results show that family-owned firms (which use family managers) are less productive than nonfamily-owned firms and are also compared to family-owned firms that use professional managers. The company's productivity range measured using the production elasticity in the family-owned firms is higher in the productivity level when hiring professional managers $12.5 \%$ compared to family managers. This finding also supports the third hypothesis which suggests that family firms should hire professional managers, not family managers to increase the firm productivity. It is because this study is able to prove that the hiring of professional managers in the family business is much more productive than family managers.
The findings of this study support the concept of cost of family management in the agency theory (Jensen \& Meckling, 1976; Anderson, Mansi, and Reeb, 2003) stating that the use of family managers can reduce the company productivity because the selection process of managers from the family members does not follow a professional criteria/ standards, so it is likely to result in selected managers with poor professional qualifications. Ultimately these low-qualified managers will decrease the firm productivity. This condition will not occur in the selection of managers from independent professionals wherein the selection process through recruitment with intense competition so that the company will get a choice of managers with excellent professional qualifications.

The findings of this study confirm Caselli \& Di-Giuli (2009) and Sciascia \& Mazzola (2008) who found that since family managers are generally recruited without requiring certain qualifications as recruitment of professional managers, family managers will tend to have lower productivity compared to professional managers. This study also confirms Barth, Gulbrandsen, \& Schøne (2005) who found family firms led by family managers characterized by being too cautious in the strategic decision making. Barth, Gulbrandsen, \& Schøne (2005) compared family businesses managed by managers from family members and family businesses managed by professional managers. The results concluded that family firms managed by professional managers are more productive than those family firms managed by family managers. Further, Barth, Gulbrandsen, \& Schøne (2005) examined the personal benefits of year-round control and usage in family ownership, the year of establishment, and preferences for family control as an instrument to choose between hiring professional managers or family managers. As a result, the owner's management may also have a negative effect because, in the owner-run family business, top managers are drawn from a limited number of talented people than when managers are recruited from the general market for managers. 
This condition causes managers to be lack of innovations that ultimately leads to lower productivity of family managers.

Furthermore, the findings of this study are also in line with Molly, Laveren, \& Deloof (2010) in a management succession study in a family-controlled firm, which found that the appointment of the successors tends to follow a period of poor operating performance in the early periods despite recovery in subsequent periods, indicating that management functions are endogenous. In ownerrun family businesses, middle managers know they have little hope of reaching top management positions in the company. Limited career prospects can serve as a disincentive for middle managers. The owner-manager has a strong preference for control. Often, these preferences may require inefficient concentration of decision-making authority in the hands of people with interest (Goffee \& Scase, 2015). Their control orientation can also prevent them from adopting new management style and personnel-style policies that will ultimately impact the decline in company productivity. According to Burkart, Panunzi, \& Shleifer (2003), this situation generally leads to lower quality among owner-managers than among professional managers and can be detrimental to company productivity. Mannarino, Pupo, \& Ricotta (2011) empirically assessed whether firms run by family managers are less or more productive than firms run by professional managers during the period 2004-2006 in Italy. The findings suggested that professional managers are more efficient in managing the business than the owner-managers/family managers. Then, the findings of this study are also in line with Bloom, Sadun, \& Van (2008), Bandiera et al. (2008), Barbera \& Moores (2013), Cucculelli et al. (2014), and Lodh, Nandy, \& Chen (2014) who found that professional managers are more productive than family managers.

From the acceptance of the three hypotheses as discussed above, this study makes an important contribution to the development of accounting science especially in Indonesia in the form of empirical evidence where family ownership negatively affects company performance as measured by firm productivity. Thus, as the first study in Indonesia to examine the effect of family ownership on productivity, these findings provide empirical evidence criticizing the findings of previous studies in Indonesia that mostly found a positive relationship between family ownership and firm performance as measured by ROA and Tobin's $Q$. This study proves that when the company performance's proxy is replaced by the firm productivity measured by the Cobb-Douglas Standard production function then the relationship becomes negative. It is in line with the argument discussed in the introduction that unlike accounting measures (ROA, ROE, and ROI) that are for external purposes which are easily manipulated by accountants, the production function is an internal measure that tends to be displayed in its real conditions. Therefore it will be more accurate to measure company performance. As for Tobin's $Q$, then this proxy will be used more accurately when the capital market is in an efficient condition with the spreading of share ownership. Due to the inefficient capital market conditions in Indonesia, the use of Standard Cobb-Douglas production function modified by Barth, Gulbrandsen, \& Schøne (2005) is more appropriate for measuring the performance of firms in Indonesia, where the majority of listed firms on the Indonesia Stock Exchange have dominant family ownership.

Another important finding of this study is that the use of professional managers will increase the company productivity compared to the use of family managers. It proves that the existing model of the agency relationship in the Indonesian listed firms tends to create an entrenchment effect rather than an alignment effect because of the dominance of family ownership. Therefore, the hiring of professional managers will be able to reduce the entrenchment effect due to the professional managers will work in accordance with the standards of professionalism. In the other word, the professional managers can be removed at any time when they per- 
form poorly, triggering them always to perform well. Meanwhile, the use of managers from the family members tends to increase entrenchment effect because they can take the rights of minority shareholders for the benefit of their group. This condition will negatively affect the company productivity.

\section{CONCLUSIONS AND SUGGESTIONS}

\section{Conclusions}

This study compares the performance of family firms and non-family firms with performance measurement using productivity as measured by Standard Cobb-Douglas production function. This study finds empirical evidence that the number of family firms in Indonesia during 2011-2015 is more than nonfamily firms with $65.97 \%$. Moreover, this study documents that family firms more prefer to hire professional managers than managers from family members. This study concludes that family ownership negatively affects the firm productivity, professional managers are more productive than family managers, and family firms will be more productive when hiring professional managers rather than family managers.

\section{Suggestions}

The practical implication of the findings of this study is that the appointment of professional man- agers would be better for family firms than the appointment of family managers. It is because the professional managers will be committed to their professional contract so they will devote their potential to improve the firm productivity, which ultimately will improve the company performance. It is also because company owners can fire professional managers at any time when they perform poorly, so professional managers will always be compelled to perform well. In other words, decreasing productivity in family firms will be minimized when the firms appoint professional managers to run the business.

Moreover, one of the limitations of this study is different from studies abroad regarding determining sample criteria based on the environmental conditions in Indonesia. Therefore, a slightly different analysis is used in determining family management and productivity relationship by using more simple analysis than previous studies abroad. For example, unlike previous studies abroad which used listed and nonlisted companies as a sample, this study only uses listed companies as a sample. So it would be more perfect if the next researchers in Indonesia can use two categories of samples, i.e., listed and nonlisted companies. Therefore, the scientific contribution in this field of study would be more optimum.

\section{REFERENCES}

Anderson, R. C., Mansi, S. A., \& Reeb, D. M. (2003). Founding family ownership and the agency costs of debt. Journal of Financial of Economics, 68(2), 263-285.

Andres, C. (2008). Large shareholders and firm performance: An empirical examination of found- ing-family ownership. Journal of Corporate Finance, 14(4), 431445.

Bambang, M., \& Hermawan, M. S. (2013). Founding family ownership and firm performance: empirical evidence from consumer goods industry in Indonesia. Journal of Applied Finance and Accounting, 4(2), 112-131.
Bandiera, O., Guiso, L., Prat, A., \& Sadun R. (2008). Italian managers: Fidelity or performance? Mimeo. London School of Economics.

Barbera, F. (2013). Financing, firm size and productive efficiency: The effect of family ownership. Ph.D. Thesis. School of Business, Bond University, Australia. 
Barbera, F., \& Moores, K. (2013). Firm ownership and productivity: A study of family and non-family SMEs. Small Business Economics, 40(4), 953-976.

Bozzi, S., Barontini, R., \& Miroshnychenko, I. (2017). Investor protection and $\mathrm{CEO}$ compensation in family firms. Corporate Ownership \& Control, 14(2), 17-29. http://doi.org/ 10.22495/cocv14i2art2.

Barth, E., Gulbrandsen, T., \& Schøne, P. (2005). Family ownership and productivity: The role of owner management. Journal of Corporate Finance, 11(1-2), 107127. https://doi.org/10.1016/ j.jcorpfin.2004.02.001.

Bennedsen, M., Fan, J. P. H., Jian, M., \& Yeh, Y. H. (2015). The family business map: Framework, selective survey, and evidence from Chinese Family Firms succession. Journal of Corporate Finance, 33(c), 212-226.

Berle, A. A., \& Means, G. C. (1932). The Modern Corporation and Private Property. New York: The Macmillan Company.

Berrone, P., Cruz, C., \& Gómez-Mejía, L. R. (2012). Socioemotional wealth in family firms: Theoretical dimensions, assessment approaches, and agenda for future research. Family Business Review, 25(3), 258-279.

Bertrand, M., Johnson, S., Samphantharak, K., \& Schoar, A. (2008). Mixing family with business: A study of Thai business groups and the families behind them. Journal of Financial Economics, 88(3), 466-498.

Bloom. N., Sadun, R., \& Van, R. J. (2008). Measuring and explaining management practices in
Italy. Rivista di Politica Economica, March-April, 15-56.

Brealey R. A., Myers S. C., \& Allen, F. (2016). Principles of Corporate Finance. $12^{\text {th }}$ ed. McGraw-Hill: New York.

Bunkanwanicha, P., Fan, J. P. H., \& Wiwattanakantang, Y. (2013). The value of marriage to family firms. Journal of Financial and Quantitative Analysis, 48(2), 611-636. https://doi.org/ 10.1017/S0022109013000148.

Burkart, M. C., Panunzi, F., \& Shleifer, A. (2003). Family firms. The Journal of Finance, 58 (5), 2167-2201.

Caselli, S., \& Di-Giuli, A. (2009). Does the CFO matter in family firms? Evidence from Italy. European Journal of Finance, 16(5),381-411. https://doi.org/10.1080/ 13518470903211657

Chaney, P. K., Faccio, M., and Parsley, D. (2011). The Quality of accounting information in politically connected firms. Journal of Accounting and Economics, 51(12), 58-76.

Chen, X., Cheng, Q., \& Dai, Z. (2007). Are US family firms subject to agency problems?: Evidence from CEO turnover and firm valuation. Proceeding of Annual Conference on Financial Economics and Accounting. The 2007 FARS Conference, and the 2007 AAA Conference.

Cucculelli, M., Mannarino, L., Pupo, V., \& Ricotta, F. (2014). OwnerManagement, firm age, and productivity in Italian Family Firms. Journal of Small Business Management, 52(2), 325-343.

Cucculelli, M., \& Micucci, G. (2008). Family succession and firm performance: Evidence from Italian Family Firms. Journal of Corporate Finance, 12(1), 17-31.
Damieni, M., Pompei, F., \& Ricci, A. (2016). Family firms and labor productivity: The role of enterprise-level bargaining in The Italian Economy. Journal of Small Business Management, November, 1-28. https://doi.org/ 10.1111/jsbm.12306.

Diyanti, V., Widyawati, L., \& Husnah, N. (2015). Family ownership and company performance: Evidence from Indonesia. Proceeding of Asia Pacific Conference on Business and Social Sciences 2015. Kuala Lumpur (in partnership with The Journal of Developing Areas).

Donaldson, L., \& Davis. J. (1991). Stewardship Theory or Agency Theory: CEO governance and shareholder returns. Academy of Management Review, 20(1), 6579.

Gedajlovic, E., \& Carney, M. (2010). Market, hierarchies, and families: Toward a transactional cost theory of the family firm. Entrepreneurship Theory and Practice, 34(6), 1145-1172.

Gul, F. A., Kim, J. B., \& Qiu, A, A. (2010). Ownership concentration, foreign shareholding, audit quality, and stock price synchronicity: Evidence from China. Journal of Financial Economics, 95(3), 425-442.

Goffee, R., \& Scase, R. (2015). Corporate Realities (Routledge Revivals): The Dynamics of Large and Small Organizations. $1^{\text {st }}$ Edition. New York: Routledge.

Gómez-Mejía, L. R., Takács Haynes, K., Núñez-Nickel, M., Jacobson, K. J. L., \& Moyano-Fuentes, J. (2007). Socioemotional wealth and business risks in familycontrolled firms: Evidence from Spanish olive oil mills. Admin- 


\section{Family Involvement in Firm's Management and Productivity: An Empirical Evidence from Indonesia}

Eko Suyono

istrative Science Quarterly, 52(1), 106-137.

Gujarati, D. N., \& Porter, D. C. (2009). Basic Econometrics. $5^{\text {th }}$ Edition. Singapore: McGraw-Hill, Book Co.

Jensen, M. C., \& Meckling, W. H. (1976). Theory of the firm: Manager behavior, agency costs, and ownership structure. Journal of Finacial Economics, 3(4), 305-360.

King, M. R., \& Santor, E. (2008). Family values: Ownership structure, performance, and capital structure of Canadian Firms. Journal of Banking and Finance, 32(11), 2423-2432.

Liu, W., Yang, H., \& Zhang, G. (2012). Does family business excel in firm performance? An Institution-Based View. Asia Pacific Journal of Management, 29(4), 965-987.

Lodh, S., Nandy, M., \& Chen, J. (2014). Innovation and family ownership: Empirical evidence from India. Corporate Governance: An International Review, 22(1), 4-23.

Lumpkin, G. T., Brigham, K. H., \& Moss, T. W. (2010). Entrepreneurial families and family firms. Entrepreneurship \& Regional Development, 22(3-4), 241-264.

Mannarino, L., Pupo, V., \& Ricotta, F. (2011). Family involvement in management and firm performance: Evidence from Italy. Working Paper No. 3. Università Della Calabria, Italy.

Martikainen, M., Nikkinen, J., \& Vahamaa, S. (2009). Production functions and productivity of family firms: Evidence from the S\&P500. Quarterly Review of Economics and Finance, 49(2), 295-307.

Molly, V., Laveren, E., \& Deloof, M. (2010). Family business succession and its impact on financial structure and performance. Family Business Review, 23(2), 131-147.

Morikawa, M. (2013). Productivity and survival of family firms in Japan. Journal of Economics and Business, 70, 111-125.

Oktavina, M., Manalu, S., \& Yuniarti, S. (2018). Pecking order and trade-off theory in capital structure analysis of family firms in Indonesia. Jurnal Keuangan dan Perbankan, 22(1): 73-82. http:// d o i .org / 10.26905 / jkdp.v22i1.1793.

Palia, D., \& Linchtenberg, F. (1999). Managerial ownership and firm performance: A re-examination using productivity measurement. Journal of Corporate Finance, 5, 323-339.

Sciascia S., \& Mazzola, P. (2008). Family involvement in ownership and management: Exploring nonlinear effects on performance. Family Business Review, 21(4), 331-345.

Singapurwoko, A. (2015). The impact of ownership structure on family firm performance: evidence from The Indonesia Stock Exchange. Proceeding of International Conference on Business, Marketing $\mathcal{E}$ Information System Management (BMISM'15). November 25-26, Paris, France.

Suyono, E. (2015). Reaksi investor terhadap pemilihan auditor spesialis industri pada perusahaan keluarga di Bursa Efek Indonesia. Jurnal Keuangan dan Perbankan, 19(1), 1-15.

Suyono, E. (2016). Family-controlled firm, governance mechanisms, and corporate performance: Evidence from Indonesia. Journal of Economics, Business, and Accountancy Ventura, 19(1), 111-124.

Villalonga, B., \& Amit, R. (2010). Family control of firms and industries. Financial Management Journal, 39(3), 863-904.

Zellweger, T. M., Eddleston, K. A., \& Kellermanns, F. W. (2010). Exploring the concept of families: Introducing family firm. Journal of Family Business Strategy, 1(1), 54-63. 